\title{
Phytopathology
}

\section{Fusarium Wilt of Banana}

\author{
Randy C. Ploetz
}

University of Florida, Tropical Research \& Education Center, 18905 SW 280th Street, Homestead 33031-3314.

Accepted for publication 1 June 2015.

\begin{abstract}
Ploetz, R. C. 2015. Fusarium wilt of banana. Phytopathology 105:1512-1521.

Banana (Musa spp.) is one of the world's most important fruits. In 2011, 145 million metric tons, worth an estimated \$44 billion, were produced in over 130 countries. Fusarium wilt (also known as Panama disease) is one of the most destructive diseases of this crop. It devastated the 'Gros Michel'-based export trades before the mid-1900s, and threatens the Cavendish cultivars that were used to replace it; in total, the latter cultivars are now responsible for approximately $45 \%$ of all production. An overview of the disease and its causal agent, Fusarium oxysporum f. sp. cubense, is presented below. Despite a substantial positive literature on biological, chemical, or cultural measures, management is largely restricted to excluding $F$. oxysporum f. sp. cubense from noninfested areas and using resistant cultivars where the pathogen has established. Resistance to Fusarium wilt is poor in several breeding targets, including important dessert and cooking cultivars. Better resistance to this and other diseases is needed. The history and impact of Fusarium wilt is summarized with an emphasis on tropical race 4 (TR4), a 'Cavendish'-killing variant of the pathogen that has spread dramatically in the Eastern Hemisphere.
\end{abstract}

Additional keywords: cooking banana, dessert banana, East African Highland bananas, Fusarium oxysporum species complex, plantain.

Banana and plantain (a type of cooking banana) rank among the world's most valuable primary agricultural commodities. In 2011, combined global production was about 145 million tons with a gross production value of US\$44 billion. Only $15 \%$ of these fruit, worth about $\$ 9$ billion year ${ }^{-1}$, are traded internationally (Table 1); they are major sources of foreign currency for the leading producers. In 2009, banana was the most important export commodity for Ecuador, Costa Rica, Panama, and Belize, and the second or third most important in Colombia, Guatemala, the Philippines, Honduras, and Cameroon (FAOSTAT 2013). The remaining 85\% is consumed by producers, or sold in local or regional markets (FAOSTAT 2013). Locally consumed bananas are staple foods or significant additions to the diets of those in Africa, southern Asia, and tropical America (Perrier et al. 2011; Van den Bergh et al. 2013).

\section{ORIGINS, TAXONOMY, AND PRODUCTION OF BANANA}

The edible bananas are predominantly hybrids between Musa acuminata and M. balbisiana (Musaceae: Zingiberales) (Perrier et al. 2011). Local and export cultivars are usually parthenocarpic, vegetatively propagated triploids that were selected in antiquity by farmers in Southeast Asia (Perrier et al. 2011). Banana was one of the first cultivated food crops. Its domestication is thought to have

Corresponding author: R. C. Ploetz; E-mail address: rcp@ifas.ufl.edu

http://dx.doi.org/10.1094/PHYTO-04-15-0101-RVW

(C) 2015 The American Phytopathological Society begun after the Pleistocene (approximately 12,000 B.P.), and there is archeological evidence that domesticates were used at least 6,500 B.P. (Denham et al. 2003; 2004).

A shorthand system is used to indicate the relative haploid contributions of these species to the cultivars: $M$. acuminata (A) and M. balbisiana (B) (Simmonds 1962; Simmonds and Shepherd 1955). For example, the Gros Michel and Cavendish cultivars are triploid, pure $M$. acuminata and thus AAA, whereas plantains are triploid, 2/3 M. acuminata, 1/3 M. balbisiana, and AAB. The Linnaean binomials $M$. paradisiaca (the AAB plantains) and $M$. sapientum (the dessert banana, 'Silk' AAB) refer to interspecific hybrids (Stover and Simmonds 1987).

Although hundreds of banana cultivars exist, few are responsible for most production (Perrier et al. 2011; Van den Bergh et al. 2013). The Cavendish subgroup is most significant, as it is responsible for most export production (about 15\% of the total) and also accounts for $28 \%$ of the locally consumed fruit. The AAB plantain subgroup, which is important in West Africa and tropical America, is responsible for an additional $21 \%$. Thus, 2 of the 50 subgroups of banana account for $64 \%$ of all production. The importance of such a limited genetic base signals a perilous situation for global production.

\section{FUSARIUM WILT (PANAMA DISEASE)}

History. The early history of this disease is tightly linked with the first banana export trades (Stover 1962; Wardlaw 1961). Many of the first reports in a given country were on damage in export 
plantations of 'Gros Michel', the banana on which the export trades were then based, and one of the disease's common names, Panama disease, refers to damage in export plantations in that country, first reported in 1890 (Brandes 1919; McKenny 1910; Ploetz 2005; Stover 1962). Throughout the banana belt, production was eliminated or became increasingly difficult. In 1933, the Governor of Jamaica indicated that the final destruction of Gros Michel was not a question of if, but when, this would occur (Anonymous 1933). He indicated that the island's banana industry depended upon the development of "an immune variety which also fulfills market requirements." Fortunately, productive Cavendish cultivars that resisted Fusarium wilt were available, and they ultimately replaced Gros Michel in the American and African trades (Stover 1962).

Simmonds (1966) considered Fusarium wilt of banana to be one of the most destructive of all plant diseases. When Stover's (1962) figures were converted to 2005 dollars (Ploetz 2005), losses in the Gros Michel-based trades totaled at least US $\$ 2$ billion. Increasing losses and the scarcity of pathogen-free soil played significant roles in the trades' conversion to the Cavendish subgroup (Stover 1962). Cavendish is resistant to race 1 of Fusarium oxysporum f. sp. cubense, the cause of the Gros Michel epidemics. As Cavendish replaced Gros Michel, Fusarium wilt disappeared as a problem for the trades (Buddenhagen 1990). Black leaf streak, caused by Mycosphaerella fijiensis, became the new primary disease, and Fusarium wilt was forgotten as a threat to the industry.

The risk of relying on such a narrow genetic base (the Cavendish cultivars are a closely related set of clones) was recognized by those who were familiar with the above history. Stover (1986) indicated that the export trades were "...extremely vulnerable to a new disease, especially a tropical race of Fusarium wilt that could devastate the basis of the industry - the Cavendish varieties." Shortly after Stover's (1986) warning, the tropical race of Fusarium wilt that he feared began to devastate Cavendish in Southeast Asia. In the 1990s, new plantations of Cavendish began to succumb in the region and a new race of $F$. oxysporum $\mathrm{f}$. sp. cubense, tropical race 4 (TR4), became apparent (Ploetz 2006b). In the ensuing decades,
TR4 spread rapidly, first within Southeast Asia but more recently to Africa and Western Asia. As of the writing of this article, TR4 had been confirmed in Australia (Northern Territory and Queensland), China (Hainan, Hunan, Guangdong, and Guangxi), Indonesia (Bali, Halmahera, Kalimantan, Java, Papua Province, Sulawesi, and Sumatra), Jordan, Lebanon, Malaysia (Peninsular and Sarawak), Mozambique, Oman, Pakistan, the Philippines (Mindanao), and Taiwan (Fig. 1) (Butler 2013; Freshplaza 2015; Garcia et al. 2013; Molina et al. 2010; Ordonez et al. 2015; Ploetz 2006b; Ploetz et al. 2015b).

Host range and variation in the pathogen. Fusarium wilt of banana is caused by a forma speciales in the $F$. oxysporum species complex (Michielse and Rep 2009; O'Donnell et al. 2009). Plant-pathogenic forms of the $F$. oxysporum species complex affect a single or limited set of host plants. F. oxysporum f. sp. cubense causes disease on species in the genus Musa, including M. acuminata, M. balbisiana, M. schizocarpa, and M. textilis (Ploetz and Pegg 2000; Waite 1954). Diverse weed hosts of the pathogen have been identified (Hennessy et al. 2005; Pittaway et al. 1999; Waite and Dunlap 1953), but they do not develop symptoms when infected (see below). A recent report, which indicated a wider host range for $F$. oxysporum f. sp. cubense (Waman et al. 2013), is probably not reliable as it utilized detached leaf assays to assess susceptibility.

Although Fusarium wilt was first reported in Australia (Bancroft 1876) and gained its greatest notoriety in tropical American export plantations (Stover 1962), the pathogen probably evolved with banana in Southeast Asia (Ploetz and Pegg 1997; Ploetz 2007; Vakili 1965). F. oxysporum f. sp. cubense has spread widely and may be the most widely disseminated banana pathogen (Ploetz 2015). Stover and Simmonds (1987) indicated that it was present in all banana-producing regions except islands in the South Pacific and Melanesia, Somalia, and countries surrounding the Mediterranean Sea. Since their summary, F. oxysporum f. sp. cubense has spread to the southwestern Pacific, Melanesia, and the Mediterranean (Ammar 2007; Davis 2005; Garcia et al. 2013; Ordonez et al. 2015; Ploetz et al. 2015b; Smith et al. 2002).

TABLE 1

Leading producers of banana in 1961 and $2011^{\mathrm{a}}$

\begin{tabular}{|c|c|c|c|c|c|c|c|}
\hline \multicolumn{4}{|c|}{ Total production } & \multicolumn{4}{|c|}{ Export production } \\
\hline Countries & 1961 & 2011 & $\%$ of 2011 total & Countries & 1961 & 2011 & $\%$ of 2011 total \\
\hline India & 2.26 & 29.67 & 20.34 & Ecuador & 0.99 & 5.78 & 30.60 \\
\hline China & 0.18 & 10.40 & 6.82 & Philippines & 0.00002 & 2.05 & 9.90 \\
\hline Ecuador & 2.82 & 8.02 & 5.85 & Costa Rica & 0.23 & 1.91 & 9.80 \\
\hline
\end{tabular}

a Figures are in millions of metric tons (FAOSTAT 2013).

FIGURE 1

Geographic distribution of tropical race 4 of Fusarium oxysporum f. sp. cubense.

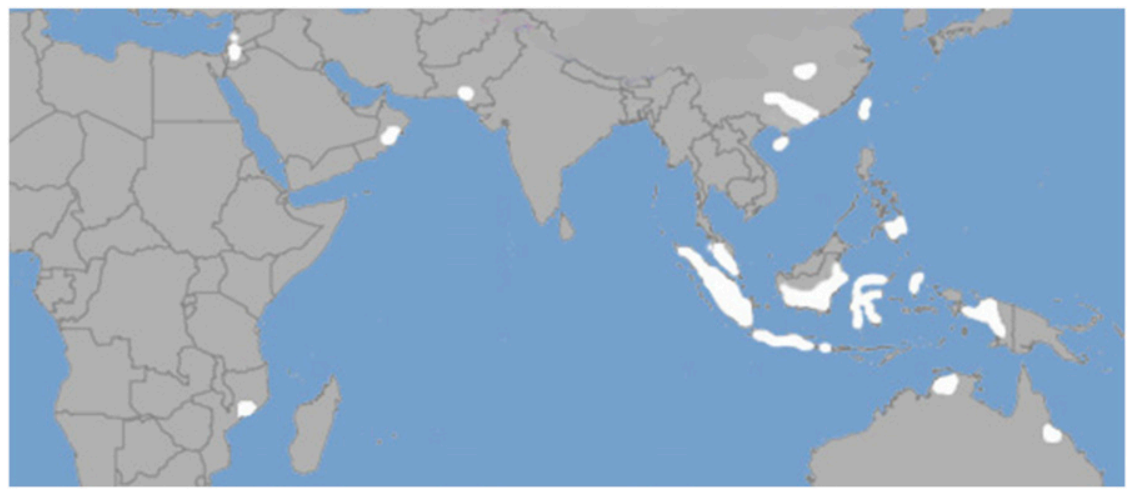


Race designations facilitate comparisons among different populations of $F$. oxysporum f. sp. cubense and are usually used when discussing the pathogen. Nonetheless, they imprecisely classify pathogenic variation in this pathogen (Ploetz 2006a, b). There is a critical need for better understandings of cultivar and host specificity in this pathogen.

Four races of $F$. oxysporum f. sp. cubense have been recognized (Ploetz et al. 2015b; Stover 1990; Stover and Buddenhagen 1986; Stover and Simmonds 1987). Race 1, which was responsible for the Gros Michel epidemics, also affects 'Maqueno' (Maia MaoliPopoulu subgroup, AAB), Silk, 'Pome' AAB, and 'Pisang Awak' ABB. Race 2 affects ABB cooking bananas, such as 'Bluggoe' (ABB). Race 4 has been split into subtropical race 4 (SR4), which affects Cavendish and race 1 and 2 suscepts in the subtropics, and TR4, which affects many of the same cultivars as SR4 but in the absence of disease-predisposing conditions that occur in the subtropics. Race 3, a pathogen of Heliconia spp. (tropical American banana relatives) (Waite 1961, 1963), is no longer recognized as a banana pathogen (Ploetz et al. 2015b).

That Cavendish succumbs to different strains of $F$. oxysporum f. sp. cubense requires some explanation. Before the TR4 outbreaks in Southeast Asia, Cavendish cultivars had been affected in the subtropics (Canary Islands, South Africa, and Australia) (Ploetz 1990), presumably due to disease-predisposing low temperatures in these areas (Moore et al. 1993; Ploetz and Pegg 2000). Several vegetative compatibility groups (VCGs) are responsible for this damage, including VCG 0120, VCG 0129, and VCG 01211. Cavendish was also affected in the tropics, but in more restricted areas and as a result of other predisposing factors. For example, Cavendish was affected in soils in Guadeloupe that were acidified by a volcanic eruption, and in waterlogged soils in Jamaica. In these and other cases, isolates that would not normally affect Cavendish in the tropics were responsible (VCGs 0120, 0124-5, and 01220 are represented) (Aguilar et al. 2000; Ploetz 1990; Ploetz and Pegg 2000; Thangavelu and Mustaff 2010). In contrast, a unique and uniform population of the pathogen, VCG 01213-01216, affects Cavendish in the tropics in good soils and under optimum conditions (Dita et al. 2010; Ploetz 2006a, b). Unlike SR4, TR4 is competent in the absence of disease-predisposing factors. Although race 4 was originally described in Taiwan before TR4 was recognized (Su et al. 1977), hindsight indicates that TR4, not SR4, is responsible for damage there (Ploetz et al. 2015b).

\section{FIGURE 2}

Tropical race 4-induced damage on Cavendish in $\mathbf{A}$ and $\mathbf{B}$, Hainin, China, and $\mathbf{C}$, Mindanao, the Philippines. A, The first external symptoms of Fusarium wilt include the chlorosis and death of the oldest leaves, which typically buckle and collapse against the pseudostem, and $\mathbf{B}$, internally include a brown to brick red discoloration of the vascular system which ranges from discrete dots to large confluent areas. C, The symptomatic mat in the upper left indicates the failure of rice hull burning

to control the disease.

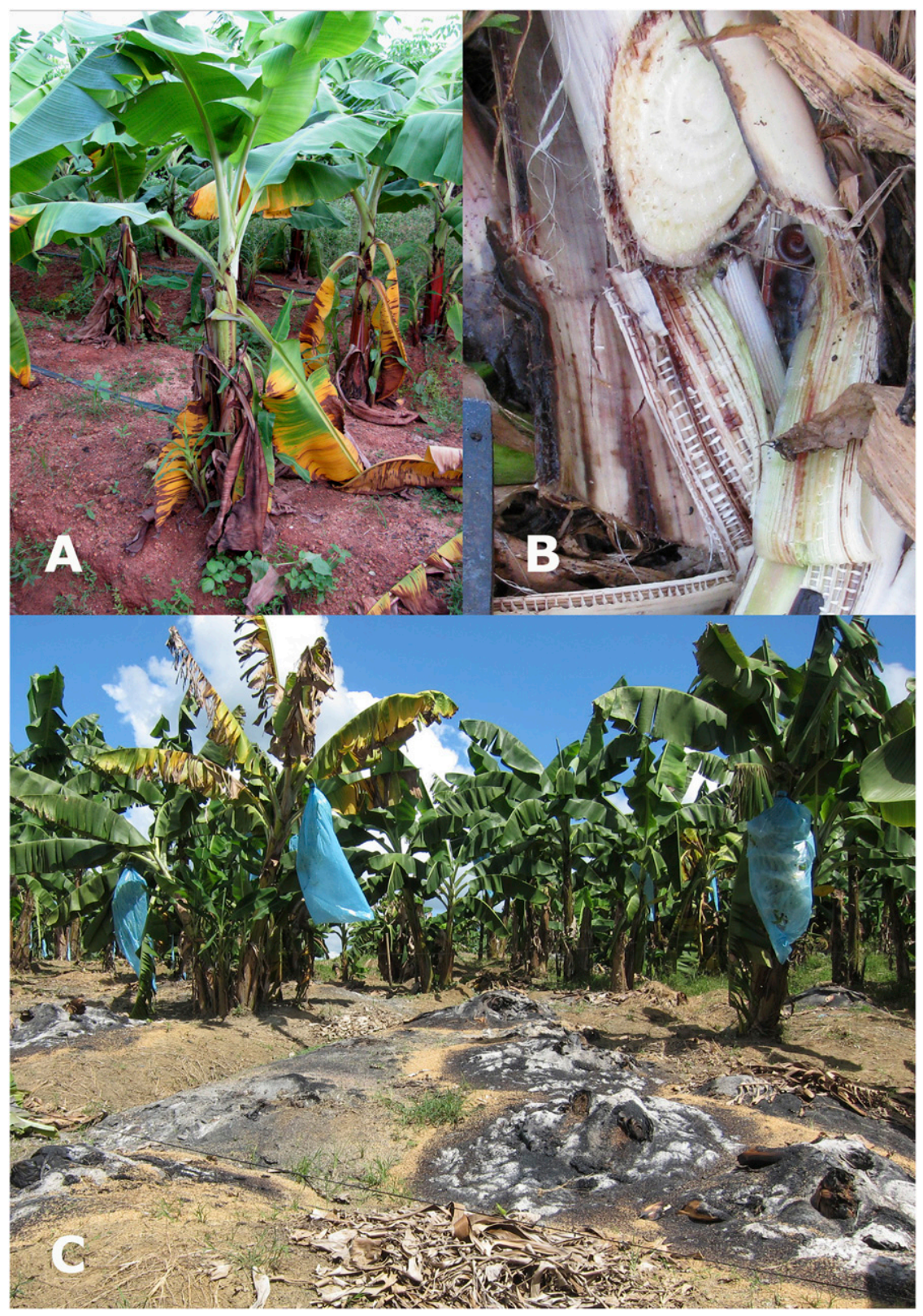


F. oxysporum f. sp. cubense has no known sexual cycle. In a global collection of the pathogen, Koenig et al. (1997) showed that gametic disequilibrium among pairs of 34 of 36 restriction fragment length polymorphic (RFLP) alleles was significantly nonrandom, and that strains with identical genotypes were widespread. These attributes supported the notion that $F$. oxysporum f. sp. cubense reproduces in a clonal manner. However, when Taylor et al. (1999) reanalyzed some of the RFLP data of Koenig et al. (1997), they noted that there was little resolution and only one internal branch in one of the largest clades identified by Koenig et al. (1997) (it contained lineages I and lineages VIII in Figure 2 as shown in Koenig et al. 1997), which was consistent with recombination. By examining the 25 unique genotypes in the lineage I + lineage VIII clade, Taylor et al. (1999) found no statistical support that isolates in the clade reproduced in a strictly clonal fashion. Whether recombination in lineages I and VIII is ongoing or occurred in the past is not clear, nor are the mechanisms by which recombination (parasexuality or sexual recombination?) occurred.

The MAT1-1 and MAT 1-2 genes that are responsible for sexual reproduction and which are found in sexual species of Fusarium are also present and expressed in isolates of the $F$. oxysporum species complex (Arie et al. 2000; Yun et al. 2000). Fourie et al. (2009) indicated that all isolates of $F$. oxysporum $\mathrm{f}$. sp. cubense that they examined possessed one or the other MATallele, but not both. They reported that perithecia (sexual fruiting structures) were not produced when any of the isolates in their study were paired, although protoperithecium-like structures were formed when isolates with different $M A T$ alleles from the same evolutionary clade were paired. Asexual ascomycetes such as these may represent potentially heterothallic strains that have either lost or have rare fertile mating partners (Kerényi et al. 2004; Turgeon 1998). If sexual reproduction occurs in these fungi, it is presumably rare (Kerényi et al. 2004). Better understandings of how and whether genetic recombination occurs in F. oxysporum f. sp. cubense are needed.

Over 20 VCGs of $F$. oxysporum f. sp. cubense have been reported, and diverse amplified fragment length polymorphisms, DNA fingerprint group, electrophoretic karyotype, random amplified polymorphic DNA, and RFLPs are recognized in global populations of the pathogen (Bentley and Bassam 1996; Bentley et al. 1998; Boehm et al. 1994; Fourie et al. 2011; Koenig et al. 1997; O'Donnell et al. 1998; Ploetz and Correll 1988; Ploetz and Pegg 2000). Several clonal lineages have been recognized in $F$. oxysporum f. sp. cubense, reflecting its polyphyletic composition, and most strains of the pathogen are in lineages that are present in Southeast Asia (Fourie et al. 2011; Koenig et al. 1997; O'Donnell et al. 1998).

Structurally, the Fusarium genome is divided into "core" and "accessory" regions (Ma et al. 2010, 2013; Rep and Kistler 2010). Core regions are vertically transmitted and perform essential functions, whereas accessory regions are located on horizontally transferred supernumerary (SP) chromosomes. SP chromosomes encode host-specific factors that are responsible for host-specific pathogenicity in the $F$. oxysporum species complex, which in F. oxysporum f. sp. cubense and other members of the $F$. oxysporum species complex is often polyphyletic (Baayen et al. 2000; O'Donnell et al. 1998). Phylogenetic relationships in the $F$. oxysporum species complex have been examined with genes from the core region (O'Donnell et al. 2009), and additional phylogenetic markers are under development (L.-J. Ma, personal communication).

Accessory genes have been examined in TR4 strain II5 (also known as CBS 102025 and NRRL 36114) (Ploetz et al. 2015a), and small secreted cysteine rich proteins (potential effectors) and candidate secondary metabolite biosynthesis gene clusters have been found (L.-J. Ma, personal communication). Interestingly, some of the $S I X$ (secreted in xylem) genes that were identified in F. oxysporum f. sp. lycopersici (Rep 2005; Rep and Kistler 2010) have also been detected in F. oxysporum f. sp. cubense. SIXI is found consistently in strains of $F$. oxysporum f. sp. cubense, and three homologs of SIX1 are found in TR4, SIX1a,b and $c$ (L.-J. Ma, personal communication; M. Rep, personal communication). Preliminary results indicate that SIXIa has a virulence function on Cavendish (M. Rep, personal communication). SIX8 is present multiple times in the subtelomeric regions of the $F$. oxysporum $\mathrm{f}$. $\mathrm{sp}$. lycopersici genome and is also found as multiple copies in strains of TR4 and SR4 (L.-J. Ma, personal communication). Polymerase chain reaction amplification revealed two SIX 8 homologs, SIX 8 a and SIX8b, in over 500 strains of $F$. oxysporum f. sp. cubense (Fraser-Smith et al. 2014). Future work should distinguish different pathotypes of $F$. oxysporum f. sp. cubense further and indicate which genetic features are responsible for host specificity and the range of cultivars that they affect.

Symptoms and epidemiology. Fusarium wilt of banana is a typical vascular wilt disease. Below, "tolerance" is used to describe cultivars that tolerate infection by $F$. oxysporum $\mathrm{f}$. sp. cubense without developing severe symptoms, whereas "resistance" is used for cultivars that overcome to some degree the effects of F. oxysporum f. sp. cubense (Zadoks and Schein 1979). Notably, F. oxysporum f. sp. cubense infects roots of both susceptible and resistant banana cultivars, but infection of vascularized portions of the rhizome is most pronounced in susceptible genotypes (Beckman 1987, 1990). Tyloses, gums, and gels are produced in xylem lumena in response to infection, but in resistant cultivars these host products are produced earlier and far more rapidly than in susceptible cultivars. Systemic infection of the pseudostem does not occur in tolerant cultivars, due to the obstruction of the pathogen by these host products, but in susceptible cultivars proceeds in advance of these host responses.

The oldest leaves of affected plants wilt, die, and often split at their base (Fig. 2A) (Stover 1962, 1972; Wardlaw 1961). Yellowing of leaf lamina is common (Fig. 2A), but nonyellowing wilt symptoms are also known. As additional leaves are affected, a bunched appearance develops at the top of the pseudostem. Younger and younger leaves develop symptoms and skirt the pseudostem, and eventually the plant collapses. Affected xylem becomes reddish brown and is eventually plugged, thereby impeding water and nutrient transport (Fig. 2B). Discontinuous flecking of the vascular tissue develops on the inner side of leaf sheaths, and symptoms do not develop on or in fruit, or on rhizomes/suckers that are 4 to 5 months old or younger.

Fusaric acid (FA), a phytotoxin that is produced by $F$. oxysporum f. sp. cubense and other members of the $F$. oxysporum species complex, has been indicted as the cause of the leaf chlorosis symptom (Dong et al. 2012, 2014). Chloroplast damage, reduced photochemical efficiency of photosystem II $\left(F_{\mathrm{V}} / F_{\max }\right)$, and a concomitant reduction in photosynthesis (net $\mathrm{CO}_{2}$ assimilation) were associated with the progression of leaf yellowing in artificially inoculated plants of Gros Michel. FA, but not the pathogen, was detected in symptomatic leaves, and chlorosis was induced after FA was injected into leaf lamina. Transpiration was reduced in diseased leaves, due to stomatal closure, and reduced hydraulic conductivity that was detected in diseased stems was associated with the development of the above symptoms (Dong et al. 2012, 2014; Page 1959). Structural and biochemical changes in affected plants were consistent with plant senescence (Dong et al. 2014).

Fusarium wilt of banana is a "polycyclic" disease (Ploetz 2015). Devastating losses can develop even when small amounts of the pathogen infest fields and the disease initially raises little concern. For example, the first outbreaks of TR4 in China and the Philippines were not taken seriously but eventually developed into uncontrollable problems (Buddenhagen 2009).

F. oxysporum f. sp. cubense is disseminated in several ways, but infected rhizomes are most efficient (Stover 1962). After the infectious nature of this disease was demonstrated by Brandes (1919), the trades established new plantations with rhizomes from disease-free portions of fields (Stover 1962). Those that exhibited vascular discoloration were discarded, and in many cases suckers 
were also washed and treated with fungicides or biocides (Stover 1962). However, even with these precautions it was still impossible to establish pathogen-free banana plantations.

Surface waters are also infested with F. oxysporum f. sp. cubense, and their use for irrigation has been responsible for the pathogen's rapid dissemination along river basins. Furthermore, F. oxysporum f. sp. cubense is moved on contaminated tools, farm equipment, clothes, and footwear (Rishbeth 1955; Stover 1962; Wardlaw 1961). Recently, Meldrum et al. (2013) detected TR4 on the exoskeletons of the banana weevil, Cosmopolites sordidus, and suggested that it was a possible vector or disease predisposing agent.

Stover (1962) indicated that banana-free rotations were ineffective measures for managing the disease, and that Gros Michel could not be produced in previously affected plantations, due to the pathogen's long survival. Twenty years is typical (Stover 1962), and 40 years have been reported (Simmonds 1966; Buddenhagen 2009). Stover (1962) suggested that chlamydospores of $F$. oxysporum $\mathrm{f}$. sp. cubense in decayed banana tissue were responsible for its durability in infested soil.

Although chlamydospores clearly enable the pathogen to survive inhospitable conditions, it seems doubtful that they would be responsible for its decades-long persistence in the absence of a living banana host. Survival as a nonpathogenic parasite of weeds may be more plausible (Ploetz 2015). Asymptomatic colonization of the roots of weeds by plant-pathogenic members of the $F$. oxysporum species complex is a common phenomenon (Altinok 2013; Hennessy et al. 2005; Pittaway et al. 1999; Postic et al. 2012; Rekah et al. 2001; Waite and Dunlap 1953). For example, in banana plantations in Australia, F. oxysporum f. sp. cubense strains in VCGs 0120 (SR4) and 01213/01216 (TR4) were recovered from surface-disinfested, asymptomatic roots of, respectively, Amaranthus sp. and Paspalum sp., and Chloris inflata, Cyanthilium cinereum, Euphorbia heterophylla, and Tridax procumberens (Hennessy et al. 2005; Pittaway et al. 1999). Hennessy et al. (2005) indicated that additional weed hosts of TR4 were probable, and suggested that management of these weeds should be considered when managing this disease. Better understandings are needed for the persistence of this pathogen in the absence of its banana host as they may assist disease management efforts and provide insight into how TR4 was moved to Africa and Western Asia.

The survival of $F$. oxysporum f. sp. cubense in banana leaf trash was recognized during the Gros Michel era (Rishbeth 1955; Wardlaw 1961). Considerable leaf trash and other banana tissues are associated with export shipments of banana fruit. In the early 2000s, the Australian government published a risk assessment for the importation of Cavendish fruit from the Philippines that considered these banana tissues as vehicles in which nonendemic strains of F. oxysporum f. sp. cubense could be moved to Australia (Commonwealth of Australia 2004). It indicated that $F$. oxysporum f. sp. cubense could move as both symptomless infections of the vasculature of fruit crowns, and in pieces of infected leaf trash that would be associated with fruit shipments. Large quantities of Cavendish fruit are exported from Mindanao to the Middle East. For example, from 2008 to 2012, export to Jordan averaged 418,000 18-kg boxes year-1, and substantial quantities of fruit were also exported to other banana-producing nations in the Middle East, including Oman and Pakistan (Republic of the Philippines 2012). Thus, there would have been ample opportunities for the introduction of TR4 to the Middle East via this route. The extent to which fruit crowns and leaf trash are reservoirs for TR4 should be examined experimentally.

Once $F$. oxysporum f. sp. cubense moves into a production area, it is very difficult to exclude from noninfested plantations. Although mixed plantings in subsistence agriculture, in which different banana cultivars are grown with other crops, typically develop moderate losses, monocultures of susceptible cultivars are usually decimated (Stover 1962).

Management. Pathogen exclusion is essential in pathogen-free regions. F. oxysporum f. sp. cubense cannot be eradicated from an area once it is infested, and exclusion of the pathogen from noninfested plantations can be very difficult once it moves into a region. Effective quarantine measures are necessary, and regional awareness and contingency programs, such as those created in the Western Hemisphere, should be considered in all threatened areas (Ploetz et al. 2015a).

Although numerous publications indicate that different methods can be used to manage this disease (Thangavelu and Mustaff 2010), there are actually few effective measures. In general, susceptible banana cultivars can be grown only if pathogen-free propagation materials are used in pathogen-free soil. Tissue-culture-derived plantlets are the most reliable source of clean material. Even though they are more susceptible to Fusarium wilt than traditional banana seed pieces (Smith et al. 1998), they should be used to propagate this crop whenever possible. In subsistence agriculture or other situations in which their expense is an issue, tissue-culture plantlets have been used to start nurseries for the production of pathogen-free conventional seed pieces (Lule et al. 2013).

Unfortunately, the perennial nature of this crop and need for longterm efficacy are seldom considered when management strategies are developed (Ploetz 2015). Much of the literature on this topic reports results from short-term in vitro or greenhouse studies with no indication that the results would be useful in the field. For example, even though many biological control studies have been conducted, none of the published results indicate that cost-effective management in the field is possible via this approach (Ploetz 2015). Likewise, limited or questionable efficacy has been associated with chemical, cultural, and physical measures (Ploetz 2015). For example, although rice hull burning (heat sterilization of the soil) has been recommended in southern Mindanao in the Philippines, and in Indonesia (Molina et al. 2010), there are no supporting data (Fig. 2C).

In $F$. oxysporum f. sp. cubense-infested soils, resistant cultivars have been the only consistently effective tool for managing this disease. Cultivars that resist different races of $F$. oxysporum f. sp. cubense exist, but may not be profitable in a given situation (Buddenhagen 1990). Xu et al. (2011) analyzed the economics of producing race 1- and TR4-resistant cultivars in China. Market preferences and the race that was present in infested fields determined which cultivars would be profitable. In infested soils in which lower rents were charged but fewer cultivars could be grown, $\mathrm{Xu}$ et al. (2011) recommended replacing susceptible cultivars with other crops or resistant cultivars.

There is a critical need for resistant bananas that meet local and export market standards (Ploetz et al. 2015b). The susceptibility of different cultivars to different races is well understood (Ploetz and Pegg 2000), but few are resistant to TR4. Dessert (Cavendish, 'Pisang mas' AA, 'Berangan' AAA, 'Mysore' AAB, Silk, and Pome) and cooking bananas (Maia-Maoli AAB, Bluggoe, and Pisang Awak) are susceptible, but there are notable exceptions (Table 2).

Molina (personal communication) indicates that a selection of 'Dwarf Pisang Awak' is resistant to TR4 in Asia. Given the importance of Pisang Awak in many areas and its consistent susceptibility to Fusarium wilt elsewhere (including to TR4 in Australia; Walduck and Daly 2007), this selection should be more widely tested and its performance against TR4 confirmed in replicated field trials. Recent results also suggest that two other subgroups that are important staple crops in Africa have useful resistance to TR4. Although the reactions of plantain hybrids from the International Institute of Tropical Agriculture (IITA) and Fundación Hondureña de Investigación Agrícola (FHIA) breeding programs (respectively, 'Bita-3' and 'FHIA21') suggested that the plantains were vulnerable (Ploetz and Evans 2015), plantain cultivars have generally done well in screening trails in China, Indonesia, and Mindanao (Huang et al. 2005; Molina et al. 2012; A. B. Molina, unpublished data). Likewise, Molina et al. (2012) indicated that East African Highland Bananas (also known as the Lujugira-Mutika subgroup) were also resistant to TR4, based on a 
TABLE 2

Response of important banana genotypes to tropical race 4 of Fusarium wilt

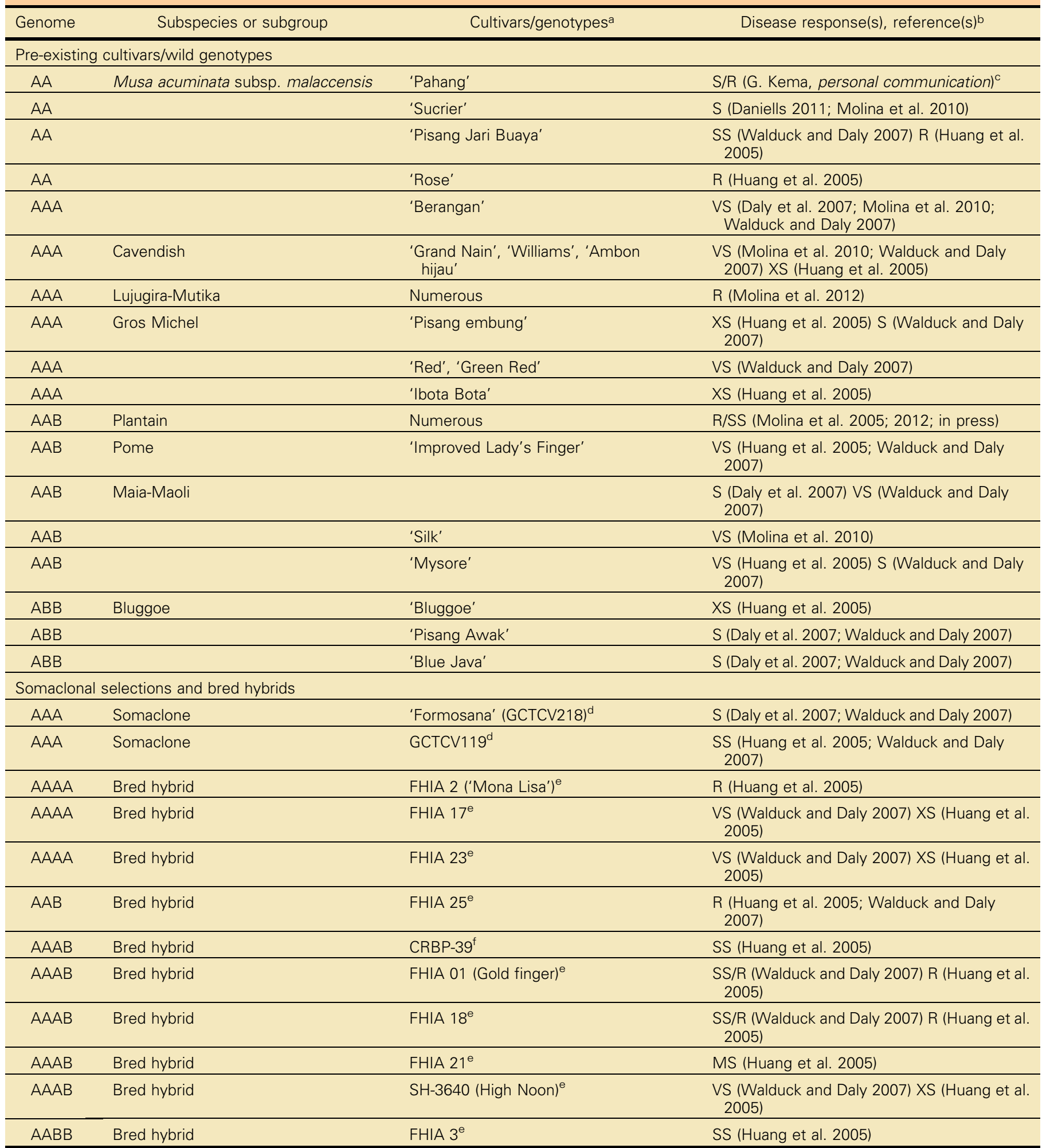

a Cultivar names are the most common internationally recognized synonym of a given clone. With the exceptions of 'Sucrier', which is a dessert banana, the other AA diploids in this table have been used primarily as parents in breeding programs.

b To enable comparisons among different sets of data, ratings from some studies were converted to a uniform scale, where: XS = extremely susceptible; VS = very susceptible; $\mathrm{S}=$ susceptible; $\mathrm{MS}=$ moderately susceptible; $\mathrm{SS}=$ slightly susceptible; and $\mathrm{R}=$ resistant.

c Seedling progeny of 'Pahang' segregate for TR4 response.

d GCTCV = Giant Cavendish Tissue Culture Variants from the Taiwan Banana Research Institute (Hwang and Ko 2004).

e Hybrids bred at the Fundación Hondureña de Investigación Agrícola (FHIA) in Honduras.

$f$ Hybrid bred at the Centre Africain de Recherches sur Bananiers et Plantains (CARBAP) in Cameroon. 
study in Mindanao and another in China. These are encouraging results, but few trials in only a few locations have been conducted. Since no trial lasted for more than 72 months, additional studies over at least two production cycles are needed. Importantly, results with these important bananas need to be reported in peer-reviewed journals.

Many banana improvement programs exist, many of which were established to improve Fusarium wilt resistance in the crop (Buddenhagen 1993; Ortiz 2013). These programs face enormous challenges. Primitive diploids that have been used as parents usually have very poor agronomic and fruit traits, and introgression of disease resistances that they possess into advanced lines can take several generations. The polyploid nature of the crop, genetic abnormalities that exist in many parental lines, the need for end products to be parthenocarpic and sterile, the low fertility of cultivars that need improvement, and the expense of evaluating large hybrid populations are additional hurdles that impede progress (Ortiz and Swennen 2014).

Resistance to TR4 is found in several bred hybrids, especially those developed by the program at the FHIA in Honduras. The FHIA hybrids have been widely disseminated and are especially important in low-input production systems. For example, FHIA hybrids that resist Fusarium wilt, as well as black leaf streak and nematodes, are significant in Africa (Dzomeku et al. 2007; Gaidashova et al. 2008; Njuguna et al. 2008; Nowakunda and Tushemereirwe 2004; Uazire et al. 2008) and Cuba (Alvarez 1997; Alvarez and Rosales 2008). Unfortunately, they do not meet the high standards that are needed for an export banana. For example, the high-yielding dessert clones 'FHIA-01' and 'FHIA-02' had lower pulp-to-peel ratios, were not as sweet, and had lower overall consumer acceptance than two Cavendish cultivars, 'Grand Nain' and 'Williams' (Dadzie 1998).

Cavendish production has a long and profitable history in Taiwan (Hwang and Ko 2004). In the 1980s, Hwang began evaluating somaclonal variants of 'Giant Cavendish' for response to Fusarium wilt. By recurrently selecting tissue cultured lines in heavily infested fields, he developed variants with improved resistance to this disease. An array of the Giant Cavendish Tissue Culture Variants (GCTCVs) have been produced, several of which are now widely tested and used in Asia (Hwang and Ko 2004). However, the GCTCV lines are not completely resistant, and can usually be grown for no more than two cycles in TR4-infested sites. Furthermore, poor finger and hand architecture of fruit produced by the GCTCV lines further complicates their use by the export trades. Nonetheless, they are currently the best TR4-resistant alternatives for the exported Cavendish clones.

Genetic transformation of banana has become commonplace, and disease resistance is one of the most sought-after traits (Khanna et al. 2007; Ortiz and Swennen 2014; Remy et al. 2013). Genetic transformation to create resistant genotypes is particularly important when improvement targets, such as the Cavendish bananas, are difficult to improve via conventional breeding (Aguilar Morán 2013). A range of transgenes have been tested, but only short-term results from greenhouse or incubator experiments are usually reported. For example, there are generally no results from race 1 (Ghag et al. 2012; Paul et al. 2011; Subramaniam et al. 2006) or TR4 field trials (Hu et al. 2013; Mahdavi et al. 2012; Yip et al. 2011). Long-term field results are needed for these bananas.

\section{CONCLUSIONS}

Given the value of export production and the importance of Cavendish for small-holders, TR4 may eventually cause even greater losses than occurred during the Gros Michel era. Greater losses will surely develop as TR4 spreads, as it is now found in only one of the world's top five producing countries and only one of the top five exporters (Table 1). To date, loss figures are available for only Indonesia, and Taiwan and Malaysia, where TR4 caused estimated losses of USD $\$ 121$ million and USD $\$ 253$ million (respectively, Hermanto et al. 2011 and Peng et al. 2013, as cited in Aquino et al. 2013). Greater losses must occur in significant Cavendish-producing countries, such as China and the Philippines.

After decades of research on managing Fusarium wilt of banana, effective alternatives to the use of resistant cultivars have not been found (Ploetz 2015). In order to manage this disease biologically, chemically, or culturally, better understandings would be needed of the factors that are responsible for disease development and how they might be manipulated for disease control. Although the complex interactions that occur between $F$. oxysporum f. sp. cubense and banana are only beginning to be understood (Bai et al. 2014; Li et al. 2013; Wang et al. 2015), virulent races of this hemibiotrophic pathogen induce apoptosis (a type of programmed cell death) in susceptible cultivars during the necrotrophic phase of host infection (Paul et al. 2011). Transgenic bananas with anti-apoptosis genes have enhanced resistance to this disease (Paul et al. 2011). Recently, transgenic lines with plant derived anti-apoptosis genes were resistant to TR4 in field studies in the Northern Territory of Australia (J. Dale, personal communication).

There is a critical need for new bananas that resist TR4 and other races of F. oxysporum f. sp. cubense (Ortiz and Swennen 2014; Rowe and Rosales 2000). However, assuming that they are produced their success may require consumers to accept new tastes and appearances in this fruit, as well as genetic transformation as a safe means for the production of new genotypes. And for some important extant bananas, such as the plantain and Eastern African highland banana cultivars, their response to TR4 needs to be detailed and described in refereed journals.

TR4 threatens export and small-holder production of Cavendish in tropical America. Preparation for its arrival and impact in the region has begun. For example, stakeholders have been informed about TR4 (Pocasangre et al. 2011) and responses have been formulated for its possible arrival in the Western Hemisphere (Dita Rodríguez et al. 2013). Similar contingency plans are needed in Africa, the Indian subcontinent, and other unaffected areas.

\section{LITERATURE CITED}

Aguilar, E. A., Turner, D. W., and Sivasithamparam, K. 2000. Fusarium oxysporum f. sp. cubense inoculation and hypoxia alter peroxidase and phenylalanine ammonia lyase activities in nodal roots of banana cultivars (Musa sp.) differing in their susceptibility to Fusarium wilt. Aust. J. Bot. 48:589-596.

Aguilar Morán, J. F. 2013. Improvement of Cavendish banana cultivars through conventional breeding. Acta Hortic. 986:205-208.

Altinok, H. H. 2013. Fusarium species isolated from common weeds in eggplant fields and symptomless hosts of Fusarium oxysporum f. sp. melongenae in Turkey. J. Phytopathol. 161:335-340.

Alvarez, J. M. 1997. Introduccion, evaluacion, multiplicacion y diseminacion de hibridos FHIA en Cuba. Infomusa 6:10-14.

Alvarez, J. M., and Rosales, F. E. (eds.) 2008. Identification and Characterization Guide for FHIA Banana and Plantain Hybrids. Bioversity International, Montpellier.

Ammar, M. I. 2007. Fusarium species associated with corm rots and wilt of banana (Musa sp.) under Egyptian conditions. Egypt. J. Phytopathol. 35:81-98. Anonymous. 1933. J. Jamaica Agric. Soc. 37:138-139.

Aquino, A. P., Bandoles, G. G., and Lim, V. A. A. 2013. R\&D and policy directions for effective control of Fusarium wilt disease of Cavendish banana in the Asia-Pacific region. FFTC Agricultural Policy Platform. http:// ap.fftc.agnet.org/ap_db.php?id=163

Arie, T., Kaneko, I., Yoshida, T., Noguchi, M., Nomura, Y., and Yamaguchi, I. 2000. Mating type genes from asexual phytopathogenic ascomycetes Fusarium oxysporum and Alternaria alternata. Mol. Plant-Microbe Interact. 13:1330-1339.

Baayen, R. P., O’Donnell, K., Bonants, P. J. M., Cigelnik, E., Kroon, L. P. N. M., Roebroeck, E. J. A., and Waalwijk, C. 2000. Gene genealogies and AFLP analyses in the Fusarium oxysporum complex identify monophyletic and nonmonophyletic formae speciales causing wilt and rot disease. Phytopathology 90:891-900.

Bai, T.-T., Xie, W.-B., Zhou, P.-P., Wu, Z.-L., Xiao, W.-C., Zhou, L., Sun, J., Ruan, X.-L., and Li, H.-P. 2014. Transcriptome and expression 
profile analysis of highly resistant and susceptible banana roots challenged with Fusarium oxysporum f. sp. cubense tropical race 4. PLoS One 8:e73945.

Bancroft, J. 1876. Report of the board appointed to enquire into the cause of disease affecting livestock and plants. Queensland, 1876. Votes and Proceedings 3:1011-1038.

Beckman, C. H. 1987. The Nature of Wilt Disease of Plants. The American Phytopathological Society, St. Paul, MN.

Beckman, C. H. 1990. Host responses to the pathogen. Pages 93-105 in: Fusarium Wilt of Banana. R. C. Ploetz, ed. The American Phytopathological Society, St. Paul, MN.

Bentley, S., and Bassam, B. J. 1996. A robust DNA amplification fingerprinting system applied to analysis of genetic variation within Fusarium oxysporum f. sp. cubense. J. Phytopathol. 144:207-213.

Bentley, S., Pegg, K. G., Moore, N. Y., Davis, R. D., and Buddenhagen, I. W. 1998. Genetic variation among vegetative compatibility groups of Fusarium oxysporum f. sp. cubense analyzed by DNA fingerprinting. Phytopathology 88:1283-1293.

Boehm, E. W. A., Ploetz, R. C., and Kistler, H. C. 1994. Statistical analysis of electrophoretic karyotype variation among vegetative compatibility groups of Fusarium oxysporum f. sp. cubense. Mol. Plant-Microbe Interact. 7:196-207.

Brandes, E. W. 1919. Banana wilt. Phytopathology 9:339-389.

Buddenhagen, I. W. 1990. Banana breeding and Fusarium wilt. Pages 107-113 in: Fusarium Wilt of Banana. R. C. Ploetz, ed. The American Phytopathological Society, St. Paul, MN.

Buddenhagen, I. W. 1993. Whence and whither banana research and development? Pages 12-26 in: Biotechnology Applications for Banana and Plantain Improvement. INIBAP, Montpellier, France.

Buddenhagen, I. W. 2009. Understanding strain diversity in Fusarium oxysporum f. sp. cubense and history of introduction of "Tropical Race 4" to better manage banana production. Acta Hortic. 828:193-204.

Butler, D. 2013. Fungus threatens top banana. Nature 504:195-196.

Commonwealth of Australia. 2004. Importation of Fresh Bananas from the Philippines. Revised Draft IRA Report. http://www.agriculture.gov. au/SiteCollectionDocuments/ba/plant/ungroupeddocs/ban_add.pdf

Dadzie, B. K. 1998. Post-harvest characteristics of black Sigatoka resistant banana, cooking banana and plantain hybrids. Technical Guidelines INIBAP 4. Intl. Plant Gen. Resour. Inst., Rome.

Daly, A., Walduck, G., Chidwick, L., and Meldrum, R. 2007. Management of the tropical race 4 strain of banana Fusarium wilt. Pages 12-15 in: Northern Territory Department of Primary Industry, Fisheries \& Mines Primary Industries. Tech. Annu. Rep. 2006-07.

Daniells, J. W. 2011. Combating banana wilts: What do resistant cultivars have to offer? Acta Hortic. 897:403-411.

Davis, R. 2005. Fusarium wilt (Panama disease) of banana. Pest Advisory Leaflet \#42. Secretariat of the Pacific Community, Suva, Fiji Islands.

Denham, T. P., Haberle, S., and Lentfer, C. 2004. New evidence and interpretations for early agriculture in Highland New Guinea. Antiquity 78:839-857.

Denham, T. P., Haberle, S. G., Lentfer, C., Fullagar, R., Field, J., Therin, M., Porch, N., and Winsborough, B. 2003. Origins of agriculture at Kuk Swamp in the highlands of New Guinea. Science 301:189-193.

Dita, M. A., Waalwijk, C., Buddenhagen, I. W., Souza, M. T., Jr., and Kema, G. H. J. 2010. A molecular diagnostic for tropical race 4 of the banana Fusarium wilt pathogen. Plant Pathol. 59:348-357.

Dita Rodríguez, M. A., Echegoyén Ramos, P. E., and Pérez Vicente, L. F. 2013. Plan de contingencia ante un brote de la raza 4 tropical de Fusarium oxysporum f. sp. cubense en un país de la región del OIRSA. Organismo Internacional Regional de Sanidad Agropecuaria, San Salvador, El Salvador.

Dong, X., Ling, N., Wang, N., Shen, Q., and Guo, S. 2012. Fusaric acid is a crucial factor in the disturbance of leaf water imbalance in Fusariuminfected banana plants. Plant Physiol. Biochem. 60:171-179.

Dong, X., Xiong, Y., Ling, N., Shen, Q., and Guo, S. 2014. Fusaric acid accelerates the senescence of leaf in banana when infected by Fusarium. World J. Microbiol. Biotechnol. 30:1399-1408.

Dzomeku, B. M., Darkey, S. K., Bam, R. K., and Arikomah, A. A. 2007. Sensory evaluation of four FHIA tetraploid hybrids for kaakle (a local dish) in Ghana. J. Plant Sci. 2:640-643.

FAOSTAT. 2013. http://faostat.fao.org/

Fourie, G., Steenkamp, E. T., Gordon, T. R., and Viljoen, A. 2009. Evolutionary relationships among the Fusarium oxysporum f. sp. cubense vegetative compatibility groups. Appl. Environ. Microbiol. 75:4770-4781.

Fourie, G., Steenkamp, E. T., Ploetz, R. C., Gordon, T. R., and Viljoen, A. 2011. Biology and evolution of Fusarium oxysporum, with specific reference to the banana wilt pathogen. Infect. Genet. Evol. 11:533-542.

Fraser-Smith, S., Czislowski, E., Meldrum, R. A., Zander, M., O’Neill, W., Balali, G. R., and Aitken, E. A. B. 2014. Sequence variation in the putative effector gene SIX8 facilitates molecular differentiation of Fusarium oxysporum f. sp. cubense. Plant Pathol. 63:1044-1052.
Freshplaza. 2015. QLD bananas: Positive TR4 diagnosis confirmed. http://www. freshplaza.com/article/136599/QLD-Bananas-Positive-TR4-diagnosisconfirmed

Gaidashova, S. V., Karemera, F., and Karamura, E. B. 2008. Agronomic performance of introduced banana varieties in lowlands of Rwanda. African Crop Sci. J. 16:9-16.

Garcia, F. A., Ordonez, N., Konkol, J., Al Qasem, M., Naser, Z., Abdel Wali, M., Salem, N. M., Waalwijk, C., Ploetz, R. C., and Kema, G. 2013. First Report of Fusarium oxysporum f. sp. cubense tropical race 4 associated with Panama disease of banana outside Southeast Asia. Plant Dis. 98:694.

Ghag, S. B., Singh, U. K. S., and Ganapathi, T. R. 2012. Petunia floral defensins with unique prodomains as novel candidates for development of Fusarium wilt resistance in transgenic banana plants. PLoS One 7:e39557.

Hennessy, C., Walduck, G., Daly, A., and Padovan, A. 2005. Weed hosts of Fusarium oxysporum f. sp. cubense tropical race 4 in northern Australia. Australas. Plant Pathol. 34:115-117.

Hu, C.-H., Wei, Y.-R., and Huang, Y. H. 2013. An efficient protocol for the production of chit42 transgenic Furenzhi banana (Musa spp. AA group) resistant to Fusarium oxysporum. In Vitro Cell. Dev. Biol. Plant 49: 584-592.

Huang, B. Z., Xu, L. B., and Molina, A. B. 2005. Preliminary evaluation of IMTP-III varieties and local cultivars against Fusarium wilt disease in South China. Pages 187-192 in: Advancing Banana and Plantain R\&D in Asia and the Pacific. Vol. 13. A. B. Molina, L. B. Xu, V. N. Roa, I. Van den Bergh, and K. H. Borromeo, eds. Intl. Network for the Improvement of Banana and Plantain-Asia Pacific, Los Baños, Laguna, Philippines.

Hwang, S.-C., and Ko, W.-H. 2004. Cavendish banana cultivars resistant to Fusarium wilt acquired through somaclonal variation in Taiwan. Plant Dis. 88:580-588.

Kerényi, Z., Moretti, A., Waalwijk, C., Oláh, B., and Hornok, L. 2004. Mating type sequences in asexually reproducing Fusarium species. Appl. Environ. Microbiol. 70:4419-4423.

Khanna, H. K., Paul, J.-V., Harding, R. M., Dickman, M. B., and Dale, J. L. 2007. The inhibition of Agrobacterium-induced cell death by antiapoptotic gene expression leads to very high transformation efficiency of banana. Mol. Plant-Microbe Interact. 20:1048-1054.

Koenig, R., Ploetz, R. C., and Kistler, H. C. 1997. Fusarium oxysporum f. sp. cubense consists of a small number of divergent and globally distributed lineages. Phytopathology 87:915-923.

Li, C., Shao, J., Wang, Y., Li, W., Guo, D., Yan, B., Xia, Y., and Peng, M. 2013. Analysis of banana transcriptome and global gene expression profiles in banana roots in response to infection by race 1 and tropical race 4 of Fusarium oxysporum f. sp. cubense. BMC Genomics 14:851.

Lule, M., Dubois, T., Coyne, D., Kisitu, D., Kamusiime, H., and Bbemba, J. 2013. Trainer's Manual. A Training Course on Setting Up and Running a Banana Tissue Culture Nursery. International Institute of Tropical Agriculture, Ibadan, Nigeria.

Ma, L.-J., Geiser, D. M., Proctor, R. H., Rooney, A. P., O’Donnell, K., Trail, F., Gardiner, D. M., Manners, J. M., and Kazan, K. 2013. Fusarium pathogenomics. Annu. Rev. Microbiol. 67:399-416.

Ma, L.-J., van der Does, H. C., Borkovich, K. A., Coleman, J. J., Daboussi, M.-J., Di Pietro, A., Dufresne, M., Freitag, M., Grabherr, M., Henrissat, B., Houterman, P. M., Kang, S., Shim, W.-B., Woloshuk, C., Xie, X., Xu, J.-R., Antoniw, J., Baker, S. E., Bluhm, B. H., Breakspear, A., Brown, D. W., Butchko, R. E. A., Chapman, S., Coulson, R., Coutinho, P. M., Danchin, E. J. G., Diener, A., Gale, L. R., Gardiner, D. M., Goff, S., Hammond-Kosack, K. E., Hilburn, K., Hua-Van, A., Jonkers, W., Kazan, K., Kodira, C. D., Koehrsen, M., Kumar, L., Lee, Y.-H., Li, L., Manners, J. M., Miranda-Saavedra, D., Mukherjee, M., Park, G., Park, J., Park, S.-Y., Proctor, R. H., Regev, A., Ruiz-Roldan, M. C., Sain, D., Sakthikumar, S., Sykes, S., Schwartz, D. C., Turgeon, B. G., Wapinski, I., Yoder, O., Young, S., Zeng, Q., Zhou, S., Galagan, J., Cuomo, C. A., Kistler, H. C., and Rep, M. 2010. Comparative genomics reveals mobile pathogenicity chromosomes in Fusarium. Nature 464:367-373.

Mahdavi, F., Sariah, M., and Maziah, M. 2012. Expression of rice rhaumatinlike protein gene in transgenic banana plants enhances resistance to Fusarium wilt. Appl. Biochem. Biotechnol. 166:10081019.

McKenny, R. E. 1910. The Central American banana blight. Science 31:750-751.

Meldrum, R. A., Daly, A. M., Tran-Nguyen, L. T. T., and Aitken, E. A. B. 2013. Are banana weevil borers a vector in spreading Fusarium oxysporum f. sp. cubense tropical race 4 in banana plantations? Australas. Plant Pathol. 42:543-549.

Michielse, C. B., and Rep, M. 2009. Pathogen profile update: Fusarium oxysporum. Mol. Plant Pathol. 10:311-324.

Molina, A. B., Fabregar, E. G., Karamura, D., Ramillete, E. B., and Sinohin, V. O. 2012. Risk assessment of Eastern African highland bananas and plantains against Fusarium oxsporum f. sp. cubense (Foc) tropical race 4 (TR4). Poster at International Banana Symposium, Tawain. http:// banana-networks.org/bapnet/files/2012/11/Risk-Assessment-EAHB1.pdf 
Molina, A. B., Viljoen, A., Fabregar, E., Karamura, D., Van den Bergh, I., Ramillete, E. B., Sinohin, V. O., Sheng, O., and Ganjun, Y. Resistance to Fusarium oxyporum f. sp. cubense in African bananas. ISHS Brisbane 2014. Acta Hortic. (In press.)

Molina, A. B., Williams, R. C., Hermanto, C., and Suwanda, B., Komolong, and Kokoa, P. 2010. Final report: Mitigating the threat of banana Fusarium wilt: Understanding the agroecological distribution of pathogenic forms and developing disease management strategies. ACIAR Publication, Canberra, Australia.

Molina, A. B., Xu, L. B., Roa, V. N., Van den Bergh, I., and Borromeo, K. H. (eds.) 2005. Advancing banana and plantain R\&D in Asia and the Pacific, Vol. 13. Proceedings of the 3rd BAPNET Steering Committee. International Network for the Improvement of Banana and Plantain-Asia Pacific, Los Baños, Laguna, Philippines.

Moore, N., Pegg, K. G., Langdon, P. W., Smith, M. K., and Whiley, A. W. 1993. Current research on Fusarium wilt of banana in Australia. Pages 270-284 in: Proceedings: International Symposium on Recent Developments in Banana Cultivation Technology. R. V. Valmayor, S. C. Hwang, R. C. Ploetz, S. W. Lee, and V. N. Roa, eds. Taiwan Banana Research Institute, Chiuju, Pingtung; INIBAP/ASPNET, Los Banos, Laguna, Philippines.

Njuguna, J., Nguthi, F., Wepukhulu, S., Wambugu, F., Gitau, D., Karuoya, M., and Karamura, D. 2008. Introduction and evaluation of improved banana cultivars for agronomic and yield characteristics in Kenya. Afr. Crop Sci. J. 16:35-40.

Nowakunda, K., and Tushemereirwe, W. 2004. Farmer acceptance of introduced banana genotypes in Uganda. Afr. Crop Sci. J. 12:1-6.

O’Donnell, K., Gueidan, C., Sink, S., Johnston, P. R., Crous, P. W., Glenn, A., Riley, R., Zitomer, N. C., Colyer, P., Waalwijk, C., van der Lee, T., Moretti, A., Kang, S., Kim, H.-S., Geiser, D. M., Juba, J. H., Baayen, R. P., Cromey, M. G., Bithell, S., Sutton, D. A., Skovgaard, K., Ploetz, R., Kistler, H. C., Elliot, M., Davis, M., and Sarver, B. A. J. 2009. A two-locus DNA sequence database for typing plant and human pathogens within the Fusarium oxysporum species complex. Fungal Genet. Biol. 46:936-948.

O’Donnell, K., Kistler, H. C., Cigelnik, E., and Ploetz, R. C. 1998. Multiple origins of the fungus causing Panama disease of banana: Concordant evidence from nuclear and mitochondrial gene genealogies. Proc. Natl. Acad. Sci. USA 95:2044-2049.

Ordonez, N., García Bastidas, F., Laghari, H. B., Akkary, M. Y., Harfouche, E. N., al Awar, B. N., Frères, D., and Kema, G. H. J. 2015. First report of Fusarium oxysporum f. sp. cubense tropical race 4 causing Panama disease in Cavendish bananas in Pakistan and Lebanon. Plant Dis. doi: 10.1094/PDIS-12-14-1356-PDN

Ortiz, R. 2013. Conventional banana and plantain breeding. Acta Hortic. 986: 177-194.

Ortiz, R., and Swennen, R. 2014. From crossbreeding to biotechnologyfacilitated improvement of banana and plantain. Biotechnol. Adv. 32:158-169.

Page, O. T. 1959. Observations of the water economy of Fusarium-infected banana plants. Phytopathology 49:61-65.

Paul, J.-V., Becker, D. K., Dickman, M. B., Harding, R. M., Khanna, H. K., and Dale, J. L. 2011. Apoptosis-related genes confer resistance to Fusarium wilt in transgenic 'Lady Finger' bananas. Plant Biotechnol. J. 9: 1141-1148.

Perrier, X., De Langhe, E., Donohue, M., Lentfer, C., Vrydaghs, L., Bakry, F., Carreel, F., Hippolyte, I., Horry, J.-P., Jenny, C., Lebot, V., Risterucci, A. M., Tomekpe, K., Doutrelepont, H., Ball, T., Manwaring, J., de Maret, P., and Denham, T. 2011. Multidisciplinary perspectives on banana (Musa spp.) domestication. Proc. Natl. Acad. Sci. USA 108:11311-11318.

Pittaway, P. A., Nasir, N., and Pegg, K. G. 1999. Soil receptivity and host pathogen dynamics in soils naturally infested with Fusarium oxysporum f. sp. cubense, the cause of Panama disease in bananas. Aust. J. Agric. Res. 50:623-628.

Ploetz, R. C. (ed.) 1990. Fusarium Wilt of Banana. The American Phytopathological Society, St. Paul, MN

Ploetz, R. C. 2005. Panama disease, an old nemesis rears its ugly head: Part 1, the beginnings of the banana export trades. Plant Health Progress. Published online. doi:10.1094/PHP-2005-1221-01-RV

Ploetz, R. C. 2006a. Fusarium wilt of banana is caused by several pathogens referred to as Fusarium oxysporum f. sp. cubense. Phytopathology 96:653-656.

Ploetz, R. C. 2006b. Panama disease: An old nemesis rears its ugly head. Part 2. The Cavendish era and beyond. Plant Health Progress. Published online. doi:10.1094/PHP-2006-0308-01-RV

Ploetz, R. C. 2007. Diseases of tropical perennial crops: Challenging problems in diverse environments. Plant Dis. 91:644-663.

Ploetz, R. C. 2015. Management of Fusarium wilt of banana: A review with special reference to tropical race 4. Crop Prot. 73:7-15.

Ploetz, R. C., and Correll, J. C. 1988. Vegetative compatibility among races of Fusarium oxysporum f. sp. cubense. Plant Dis. 72:325-328.

Ploetz, R. C., and Evans, E. A. 2015. Banana diseases and the future of the industry. Hortic. Rev. (Am. Soc. Hortic. Sci.) 43:311-351.
Ploetz, R. C., Freeman, S., Konkol, J., Al-Abed, A., Naser, Z., Shalan, K., Barakat, R., and Israeli, Y. 2015a. Tropical race 4 of Panama disease in the Middle East. Phytoparasitica 43:283-293.

Ploetz, R. C., Kema, G. H. J., and Ma, L.-J. 2015b. Impact of diseases on export and smallholder production of banana. Annu. Rev. Phytopathol. 53: 269-288.

Ploetz, R. C., and Pegg, K. G. 1997. Fusarium wilt of banana and Wallace's line: Was the disease originally restricted to his Indo-Malayan region? Australas. Plant Pathol. 26:239-249.

Ploetz, R. C., and Pegg, K. G. 2000. Fusarium wilt. Pages 143-159 in: Diseases of Banana, Abaca and Enset. D. R. Jones, ed. CABI Publishing, Wallingford, UK.

Pocasangre, L. E., Ploetz, R. C., Molina, A. B., and Perez Vicente, L. 2011. Raising awareness of the threat of Fusarium wilt tropical race 4 in Latin America and the Caribbean. Acta Hortic. 897:331-337.

Postic, J., Cosic, J., Vrandecic, K., Jurkovic, D., Saleh, A. A., and Leslie, J. F. 2012. Diversity of Fusarium species isolated from weeds and plant debris in Croatia. J. Phytopathol. 160:76-81.

Rekah, Y., Shtienberg, D., and Katan, J. 2001. Role of the shrub Tamarix nilotica in dissemination of Fusarium oxysporum f. sp. radicis-lycopersici. Plant Dis. 85:735-739.

Remy, S., Kovács, G., Swennen, R., and Panis, B. 2013. Genetically modified bananas: Past, present and future. In: Proc. 2nd Genetically Modified Organisms in Horticulture Symposium. M. A. Veale, ed. Acta Hortic. 974: 71-80.

Rep, M. 2005. Small proteins of plant-pathogenic fungi secreted during host colonization. FEMS Microbiol. Lett. 253:19-27.

Rep, M., and Kistler, H. C. 2010. The genomic organization of plant pathogenicity in Fusarium species. Curr. Opin. Plant Biol. 13:420-426.

Republic of the Philippines. 2012. Advisory No. RBXI-01. Advisory on the Implementation of productivity-based incentive schemes for the banana industry in Davao Region. http://www.ro11.dole.gov.ph/fndr/mis/files/ Advisory-No-RBXI-01.pdf

Rishbeth, J. 1955. 'Fusarium' wilt of bananas in Jamaica. I. Some observations on the epidemiology of the disease. Ann. Bot. (Lond.) 19:293.

Rowe, P., and Rosales, F. 2000. Conventional banana breeding in Honduras. Pages 435-449 in: Diseases of Banana, Abaca and Enset. D. R. Jones, ed. CAB Intl., Oxforshire, UK.

Simmonds, N. W. 1962. The Evolution of the Bananas. Longman, London.

Simmonds, N. W. 1966. Bananas. Longman, London.

Simmonds, N. W., and Shepherd, K. 1955. The taxonomy and origins of the cultivated bananas. J. Linn. Soc. Lond. Bot. 5:302-312.

Smith, L. J., Moore, N. Y., Tree, D. J., Bentley, S., and Pattemore, J. 2002. First record of Fusarium oxysporum f. sp. cubense from Yap, Federated States of Micronesia. Australas. Plant Pathol. 31:101.

Smith, M. K., Whiley, A. W., Searle, C., Langdon, P. W., Schaffer, B., and Pegg, K. G. 1998. Micropropagated bananas are more susceptible to Fusarium wilt than plants grown from conventional material. Aust. J. Agric. Res. 49:1133-1139.

Stover, R. H. 1962. Fusarial wilt (Panama disease) of bananas and other Musa species. Commonwealth Mycological Inst., Kew, UK.

Stover, R. H. 1972. Banana, Plantain and Abaca Diseases. Commonwealth Mycological Institute, Kew, UK.

Stover, R. H. 1986. Disease management strategies and the survival of the banana industry. Annu. Rev. Phytopathol. 24:83-91.

Stover, R. H. 1990. Fusarium wilt of banana: Some history and current status of the disease. Pages 1-7 in: Fusarium Wilt of Banana. R. C. Ploetz, ed. The American Phytopathological Society, St. Paul, MN.

Stover, R. H., and Buddenhagen, I. W. 1986. Banana breeding: Polyploidy, disease resistance and productivity. Fruits 41:175-191.

Stover, R. H., and Simmonds, N. W. 1987. Bananas, 3rd ed. Longmans, London, UK.

Su, H. J., Chuang, T. Y., and Kong, W. S. 1977. Physiological race of fusarial wilt fungus attacking Cavendish banana of Taiwan. Taiwan Banana Res. Inst. Spec. Pub. 2:1-21.

Subramaniam, S., Maziah, M., Sariah, M., Puad, M. P., and Xavier, R. 2006. Bioassay method for testing Fusarium wilt disease tolerance in transgenic banana. Sci. Hortic. (Amsterdam) 108:378-389.

Taylor, J. W., Jacobson, D. J., and Fisher, M. C. 1999. The evolution of asexual fungi: Reproduction, speciation and classification. Annu. Rev. Phytopathol. 37:197-246.

Thangavelu, R., and Mustaff, M. M. 2010. First report on the occurrence of a virulent strain of Fusarium wilt pathogen (Race-1) infecting Cavendish (AAA) group of bananas in India. Plant Dis. 94:1379.

Turgeon, B. G. 1998. Application of mating type gene technology to problems in fungal biology. Annu. Rev. Phytopathol. 36:115-137.

Uazire, A. T., Ribiero, C. M., Musanne, R. B. C., Pillay, M., Blomme, G., Fraser, C., and Karamura, E. 2008. Preliminary evaluation of improved banana varieties in Mozambique. Afr. Crop Sci. J. 16:17-25. 
Vakili, N. G. 1965. Fusarium wilt resistance in seedlings and mature plants of Musa species. Phytopathology 55:135-140.

Van den Bergh, I., Vézina, A., and Picq, C. 2013. Where bananas are grown. ProMusa. Bioversity International. http://www.promusa.org/tiki-index.php? page $=$ Banana-producing + countries + portal

Waite, B. H. 1954. Vascular disease of abaca or Manila hemp in Central America. Plant Dis. Rep. 38:575-578.

Waite, B. H. 1961. Variability and pathogenesis in Fusarium oxysporum f. cubense. Ph.D. thesis, University of California, Berkeley.

Waite, B. H. 1963. Wilt of Heliconia spp. caused by Fusarium oxysporum f. sp. cubense race 3. Trop. Agric. 40:299-305.

Waite, B. H., and Dunlap, V. C. 1953. Preliminary host range studies with Fusarium oxysporum f. cubense. Plant Dis. Rep. 37:79-80.

Walduck, G., and Daly, A. 2007. Banana Tropical Race 4 Panama Disease Management. Pages 7-11 in: Northern Territory Department of Primary Industry, Fisheries \& Mines Primary Industries. Tech. Annu. Rep. 2006-07.

Waman, A. A., Bohra, P., Sathyanarayana, B. N., Chandrashekar, S. C., and Rani, R. T. 2013. Are bananas (Musa spp.) really safe from their aesthetic relatives? Screening potential alternative hosts of Fusarium oxysporum f. sp. cubense. J. Hortic. Sci. Biotechnol. 88:559-562.

Wang, Z., Jia, C., Li, J., Huang, S., Xu, B., and Jin, Z. 2015. Activation of salicylic acid metabolism and signal transduction can enhance resistance to Fusarium wilt in banana (Musa acuminata L. AAA group, cv. Cavendish). Funct. Integr. Genomics 15:47-62.

Wardlaw, C. W. 1961. Banana Diseases Including Plantain and Abaca. John Wiley \& Sons, Inc., New York.

Xu, L., Huang, B., Wu, Y., Huang, Y., and Dong, T. 2011. The cost-benefit analysis for bananas diversity production in China Foc zones. Am. J. Plant Sci. 2:561-568.

Yip, M.-K., Lee, S.-W., Su, K.-C., Lin, Y.-H., Chen, T.-Y., and Feng, T.-Y. 2011. An easy and efficient protocol in the production of pflp transgenic banana against Fusarium wilt. Plant Biotechnol. Rep. 5:245-254.

Yun, S.-H., Arie, T., Kaneko, I., Yoder, O. C., and Gillian Turgeon, B. 2000. Molecular organization of mating type loci in heterothallic, homothallic, and asexual Gibberella/Fusarium species. Fungal Genet. Biol. 31:7-20.

Zadoks, J. C., and Schein, R. D. 1979. Epidemiology and Plant Disease Management. Oxford University Press, Oxford, UK. 